\title{
Space Infections of the Head and Neck - The "New" Clinical Picture
}

\author{
Maj D G R Evans* \\ MRCP, RAMC
}

\section{Capt D Robertson \\ $\mathrm{MB}, \mathrm{ChB}, \mathrm{DCH}, \mathrm{RAMC}$}

\author{
Maj J D C Bennett ${ }^{\dagger}$ \\ BSc, FRCS, DCH, RAMC \\ Department of Paediatrics, British Military Hospital Rinteln
}

\begin{abstract}
SUMMARY: A series of 12 neck space infections admitted to a military hospital in Germany in a 12 month period are presented. This represents an incidence of 1:1000 for the age group studied. The reappearance of the retropharyngeal abscess which has been rare since the widespread use of antibiotics, along with the generally high incidence of this group of infections, is probably a result of the more discriminating use of antibiotics in primary health care. The pitfalls in diagnosis and the preferred antibiotic cover are discussed.
\end{abstract}

\section{Introduction}

Upper airway infections are the commonest cause for children to be seen by a general practitioner(1). Modern therapy with broad spectrum antibiotics has greatly reduced the incidence of complications such as the spread of infection to the surrounding fascial planes(2). There has been a tendency in recent years to restrict the prescribing of antibiotics for non-specific upper respiratory infections in children. It has been considered that there may be a concomitant increase in the incidence of neck space infections(3). The higher than predicted incidence in our hospital prompted us to undertake a prospective study.

\section{Pathology}

Neck space infections in children usually present with a swelling on the side of the neck behind the angle of the mandible (Fig 1). This reflects lymphatic drainage to the abundant cervical nodes present in this age group. The origin of the infection is commonly odontogenic or from the upper airway, but this is often difficult to identify. More rarely intubation, endoscopy, blunt trauma, foreign body ingestion and insect bites may also precipitate sepsis. Abscess formation within the retropharyngeal space is less common. It is reported that $96 \%$ occur in children under the age of 6 years and this is probably due to atrophy of the lymphatic tissue there after this age(4).

\section{Patients and Methods}

All children presenting with an abscess in the neck over a 12 month period ending in November 1989 were included in the study. There were 12 cases in all, with ages ranging from 7.5 months to 6.5 years. Eleven cases proceeded to surgery. The criterion for diagnosis of retropharyngeal abscess (RPA) was an extended lateral neck X-ray showing a soft tissue retropharyngeal mass

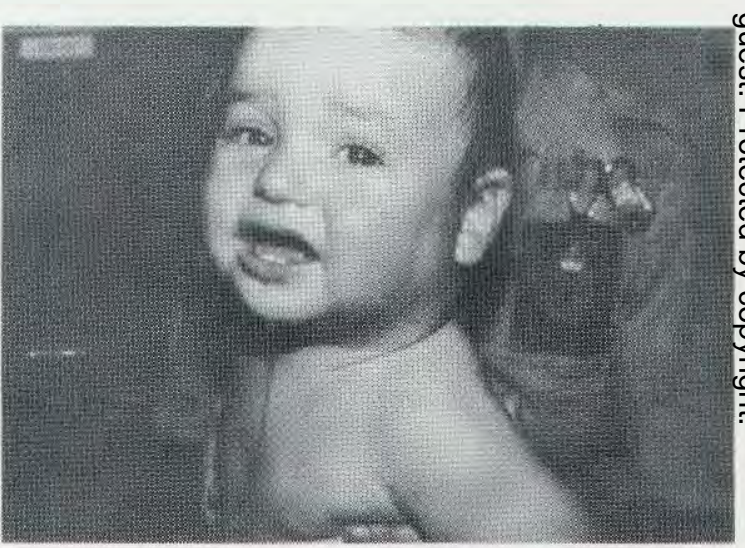

Fig 1. Case 2 note neck swelling and drooling.

measuring twice the antero-posterior diameter of the corresponding cervical vertebra(3) (Fig 2). It is essential to get a well aligned true extended view or the apparent soft tissue mass appears larger. Confirmation by surgical drainage was achieved in each case by the intraoral approach.

\section{Results}

The clinical findings and investigations of all twelve cases are shown in Table 1 . There were 3 cases of RPA. A recent report from a major centre had only 16 in a 30 year period(3). Our 3 cases of RPA presented in an identical fashion to all our other cases, with a marked unilateral neck swelling. Only in case 6 , a baby with Down's syndrome who had developed respiratory obstruction, were there any further grounds for suspicion. This baby's stridor was abolished after intraoral drainage and incision through the posterior 


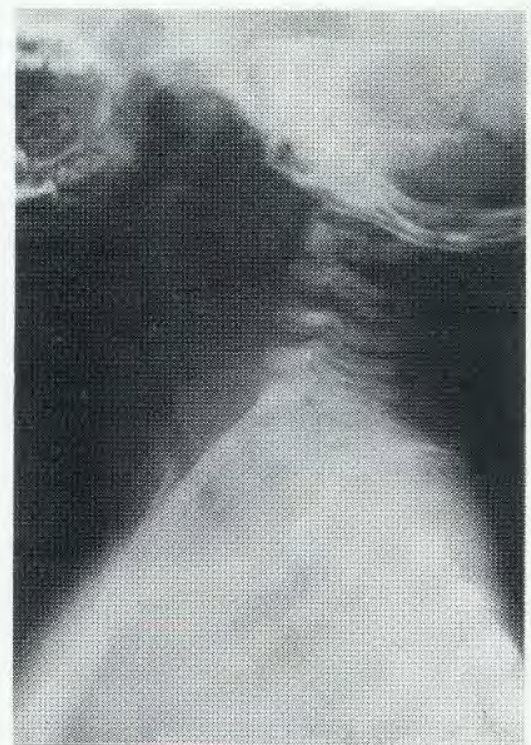

Fig 2. Lateral radiograph of the neck, case 6. Note massive swelling of retropharyngeal space pushing trachea forward. These are the appearances of a retropharyngeal abscess.

pharynx. In this case and both the others who had not received antibiotic therapy, no erythema or pointing of the posterior pharynx was seen even at operation. Without looking specifically for RPA, with a lateral neck $\mathrm{X}$-ray, it would have been very easy to miss this potentially life threatening condition.

In the neck space infection group as a whole, 10 cases $(83 \%)$ presented with a unilateral swelling at the angle of the mandible. This lead to an initial diagnosis of mumps in 4 of these children. However, by the time of admission every swelling was accompanied by erythema.

The average duration of symptoms before admission was 7.75 days with a range of 2 to 20 days. The average age was 2.45 years. The criterion for admission was a clinically significant neck swelling. The numbers admitted represent an annual incidence of $1: 1000$ in the age group and population studied. However, despite this being a considerable increase in the incidence as compared to previous reports(3), the numbers are still too small to draw statistically significant conclusions regarding clinical presentation. It is interesting to note that $83 \%$ showed a leucocytosis on full blood count. Only $75 \%$ had a pyrexia, but $50 \%$ had the triad of neck swelling, pyrexia and poor feeding.

In 9 of the cases a lateral X-ray of the neck was performed. This showed an abnormality in 5. In 33\% a retropharyngeal abscess was apparent. No reliance was placed on ultrasound, although this has been shown to be useful in some hands $(5,6)$.
One case was managed with antibiotics alone but in the remaining 11 cases pus was surgically aspirated. In $7 \geq$ cases Staphylococcus aureus or a Streptococcus spp was $\mathbb{\mathbb { Q }}$ cultivated. No anaerobes were found despite being $\Omega$ sought. The timing of surgery was variable; 5 cases were drained within 6 hours of admission. Three cases were initially managed with intravenous antibiotics, but later $\vec{\Rightarrow}$ required surgical drainage. Two cases were successfully $\stackrel{P}{P}$ managed by needle aspiration .

\section{Discussion}

Antibiotics were not prescribed prior to admission in 9 cases $(75 \%)$ and of the 3 receiving antibiotics, only 1 क received those appropriate for a staphylococcal $\overrightarrow{0}$ infection. Lack of antibiotic therapy could be due to a policy not to prescribe for non-specific infection, or to a misdiagnosis. In four cases (33\%) the initial diagnosis had been mumps. With increased utilisation of measles, $\frac{\mathfrak{N}}{3}$ mumps and rubella (MMR) vaccination this pitfall may become less common. Every blood culture proved $\vec{\omega}$ negative but culture of pus showed a similar picture to $\hat{O}$ previous reports $(7,8)$. This emphasises the need for an anti-staphylococcal agent. Benzyl penicillin, fluclox $\infty$ cillin and metronidazole would have covered all bactere⿻ isolated.

Lateral X-rays of the neck were only performed on of the cases and a third of these were found to have retropharyngeal abscess. The overall incidence mig have been higher with the unsuspected conditio responding to antibiotics and extra-oral drainage. higher index of suspicion and more careful investigatio요 may reveal an incidence higher than previous expected.

The initial referral was made to one of three departments - surgery, paediatrics and otolaryngology. Circumstances vary between different hospitals but it might be better for a uniform policy to be adopted.

\section{Conclusion}

It seems likely that the incidence of neck space infection amongst children is increasing. This may be due to reticence amongst general practitioners to prescribe antibiotics as frequently as might have been the case formerly. Advances made since pre-antibiotic days include ultrasound investigation but the most useful asset in the management of these cases is diagnostic awareness and prompt treatment with antibiotics intravenously.

\section{REFERENCES}

1. Phelan P D, Landau L I, Olinsky A. Respiratory Illness In Children. Oxford: Blackwell Scientific Publications, 1986.

2. Wills P I, Vernon R P. Complications of space infections of the head and neck. Laryngoscope 1981; 91: 1129-1135.

3. YEOH L H, SingH S D, Rogers J H. Retropharyngeal abscesses in a children's hospital. J Laryngol Otol 1985;99: $555-566$. 
Table 1

Clinical details of children with neck abscesses

\begin{tabular}{|c|c|c|c|c|c|c|c|}
\hline Case & $\begin{array}{c}\text { Duration } \\
\text { of } \\
\text { history }\end{array}$ & $\begin{array}{l}\text { Antibiotics } \\
\text { prior to } \\
\text { admission }\end{array}$ & $\begin{array}{l}\text { White } \\
\text { blood } \\
\text { count }\end{array}$ & $\begin{array}{l}\text { Swab } \\
\text { culture }\end{array}$ & $\begin{array}{c}\text { Age } \\
\text { (years) }\end{array}$ & $\begin{array}{c}\text { Symptoms } \\
\text { /signs* }\end{array}$ & $\begin{array}{cc}\text { Lateral } & 0 \\
\text { neck } & 0 \\
\text { X-rays } & \frac{0}{0} \\
\end{array}$ \\
\hline 1 & 2 & none & 14.7 & no growth & 2.0 & $1,2,3$ & normal \\
\hline 2 & 5 & none & not done & $\begin{array}{c}\text { Strep } \\
\text { pneumoniae }\end{array}$ & 0.7 & $1,2,8$ & not done \\
\hline 3 & 13 & none & not done & $\begin{array}{l}\text { beta-haem } \\
\text { Strep }\end{array}$ & 2.0 & $1,2,8$ & normal \\
\hline 4 & 5 & $\begin{array}{c}\text { amoxycillin } \\
4 \text { days }\end{array}$ & not done & $\begin{array}{l}\text { Staph } \\
\text { aureus }\end{array}$ & 4.1 & 2,8 & normal \\
\hline 5 & 10 & none & 21.1 & $\begin{array}{l}\text { Staph } \\
\text { aureus }\end{array}$ & 2.5 & $1,2,3$ & $\begin{array}{l}\text { anterior soft } \\
\text { tissue swelling }\end{array}$ \\
\hline 6 & 7 & $\begin{array}{c}\text { amoxycillin } \\
7 \text { days }\end{array}$ & 6.6 & no growth & 0.7 & $1,2,3,4,5,7$ & RPA \\
\hline 7 & 20 & $\begin{array}{c}\text { amoxycillin }+ \\
\text { flucloxacillin } \\
7 \text { days }\end{array}$ & not done & $\begin{array}{l}\text { Staph } \\
\text { aureus }\end{array}$ & 3.2 & 2 & not done \\
\hline 8 & 3 & none & not done & no growth & 6.5 & $1,2,4$ & normal $\varrho \dot{c}$ \\
\hline 9 & 6 & none & not done & $\begin{array}{l}\text { Staph } \\
\text { aureus }\end{array}$ & 2.0 & 2 & 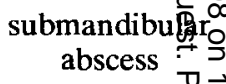 \\
\hline 10 & 2 & none & 29.8 & no growth & 2.0 & $1,2,3,4,6$ & not done \\
\hline 11 & 17 & none & 37.8 & beta-haem & 1.0 & $1,2,3,4$ & RPA $\stackrel{\overrightarrow{\mathbb{D}}}{\stackrel{\mathbb{D}}{口}}$ \\
\hline 12 & 3 & none & 30.9 & no growth & 2.7 & $1,2,3,6$ & RPA $\overrightarrow{\mathbb{Q}} \stackrel{2}{2}$ \\
\hline
\end{tabular}

${ }^{*}$ Code: 1 pyrexia; 2 neck swelling; 3 poor feeding; 4 neck stiffness; 5 stridor; 6 sore throat; 7 drooling; 8 initial diagnosis of mumps; RPA Retropharyngeal abscess.

4. BRown J M. Acute retropharyngeal abscess in children. Laryngoscope 1919; 29: 9-12.

5. Chodosh P L, Silbey R, Oen K T. Diagnostic use of ultrasound in diseases of the head and neck. Laryngoscope 1980; 90: 814-821.

6. SIEGERT R. Ultrasonography of inflammatory soft tissue swellings of the head and neck. J Oral Maxillofac Surg 1987; 45: 842-846.
7. BECK A H. Deep neck infections. Ann Otol 1947; 56

8. BROOK I. Microbiology of retropharyngeal abscesses in children. Am J Dis Child 1987; 141: 202-204. 